\title{
Granulomatous pneumonia due to pythiosis in captive South American coatis (Nasua nasua) ${ }^{1}$
}

\author{
Kalinne S. Bezerra², Tarcísio A. Santos ${ }^{2}$, Janaina M.A. Rosa², Carolina A. Pescador², \\ Valeria Dutra ${ }^{2}$, Luciano Nakazato ${ }^{2}$, David Driemeier ${ }^{3}$ and Edson M. Colodel ${ }^{2 *}$ (D)
}

\begin{abstract}
Bezerra K.S., Santos T.A., Rosa J.M.A., Pescador C.A., Dutra V., Nakazato L., Driemeier D. \& Colodel E.M. 2020. Granulomatous pneumonia due to pythiosis in captive South American coatis (Nasua nasua). Pesquisa Veterinária Brasileira 40(8):647-650. Laboratório de Patologia Veterinária, Hospital Veterinário, Faculdade de Medicina Veterinária, Universidade Federal de Mato Grosso, Av. Fernando Corrêa da Costa 2367, Boa Esperança, Cuiabá, MT 78068-495, Brazil. E-mail: moleta@gmail.com

Pythiosis is an emerging infectious disease affecting captive and free-ranging wild animals. We report granulomatous pneumonia due to Pythium insidiosum in two South American coatis (Nasua nasua), who were found dead without any clinical records. Severe granulomatous pneumonia associated with pleural effusion was revealed in the necropsy. Microscopically, variably sized granulomas and pyogranulomas presented negative hyphae profiles at the periphery of their necrotic cores. Grocott methenamine silver stain highlighted these structures, and immunostain (anti- P. insidiosum) was strongly positive. Molecular analysis by polymerase chain reaction amplified $P$. insidiosum specific DNA. These findings characterized $P$. insidiosum as a cause of granulomatous pneumonia in coatis and proved that pythiosis needs to be considered in the differential diagnosis of respiratory diseases affecting this species in endemic areas.
\end{abstract}

INDEX TERMS: Granulomatous pneumonia, pythiosis, captive animals, South America, coatis, Nasua nasua, pneumonia, Procyonidae, Pythium insidiosum, Southern coati, Stramenopila.

RESUMO.- [Pneumonia granulomatosa decorrente de pitiose em quatis sul-americanos (Nasua nasua) de cativeiro.] A pitiose é uma doença infecciosa emergente que afeta animais silvestres de cativeiro e em vida livre. Reportamos dois casos de pneumonia granulomatosa decorrentes da infecção por Pythium Insidiosum em quatis sul-americanos (Nasua nasua), que foram encontrados mortos sem apresentar nenhum quadro clínico prévio. Pneumonia granulomatosa severa associada a efusão pleural foi observada durante a necropsia. Na microscopia, foram observados múltiplos granulomas e piogranulomas de tamanhos variados que continham imagens negativas de hifas na periferia de seus centros necróticos. A coloração de metenamina de prata (Grocott) evidenciou estas estruturas, e a imunomarcação (anti-P. insidiosum)

\footnotetext{
${ }^{1}$ Received on March 16, 2020.

Accepted for publication on April 20, 2020.

${ }^{2}$ Faculdade de Medicina Veterinária (Favet), Universidade Federal de Mato Grosso (UFMT), Av. Fernando Corrêa da Costa 2367, Boa Esperança, Cuiabá, MT 78068-495, Brazil. *Corresponding author: moleta@gmail.com

${ }^{3}$ Departamento de Patologia e Clínica Veterinária, Faculdade de Veterinária (Favet), Universidade Federal do Rio Grande do Sul (UFRGS), Av. Bento Gonçalves 9090, Agronomia, Porto Alegre, RS 91540000, Brazil.
}

foi fortemente positiva. A análise molecular pela reação de polimerase em cadeia amplificou o DNA específico do $P$. insidiousum. Estes achados caracterizaram o P. insidiosum como a causa da pneumonia granulomatosa nos quatis e provou que a pitiose deve ser considerada um diagnostico diferencial para outras doenças respiratórias que afetam esta espécie.

TERMOS DE INDEXAÇÃO: Pneumonia granulomatosa, pitiose, quatis, América do Sul, Nasua nasua, cativeiro, Procynidae, Pythium insidiosum, quati, Stramenopila.

\section{INTRODUCTION}

Pythium insidiosum (kingdom: Stramenopila, phylum: Pseudofungi, class: Oomycetes, order: Pythiales, family: Pythiaceae) is the causative agent of pythiosis and an emerging pathogen in captive and free-ranging wild animals (Wellehan et al. 2004, Buergelt et al. 2006, Pesavento et al. 2008, Gaastra et al. 2010, Videla et al. 2012). It is commonly known for causing chronic and granulomatous disease in humans and domestic animals, particularly horses. Recently, it has become 
significant in zoos and feral herds, such as the wild ponies in Chincoteague Island (Gaastra et al. 2010, Hedgpeth 2018).

Usually associated with aquatic environments, it can manifest as mild to severe tumor-like masses or ulcerated lesions that can affect any part of the body depending on the species (Gaastra et al. 2010). They can be cutaneous, subcutaneous or gastrointestinal (Tabosa et al. 2004, Buergelt et al. 2006, Pesavento et al. 2008, Gaastra et al. 2010). As the disease progresses, the infection can spread to the lungs or other sites (Grooters 2003, Reis et al. 2003, Tabosa et al. 2004, Gaastra et al. 2010, Gaddis \& Brinkman 2017). Pneumonia rarely occurs as a primary infection, and seems to have been limited to a single case report of a Central American jaguar among non-domestic species (Camus et al. 2004). As it is a life-threatening condition, an accurate and early diagnosis is critical to improve prognosis (Gaastra et al. 2010). However, unusual presentations like pulmonary pythiosis could be difficult to detect and easily overlooked.

South American coatis, Southern coatis, brown-nosed coatis, or ring-tailed coatis (Nasua nasua) are members of the Procyonidae family and broadly distributed in South America (Desbiez \& Borges 2010). Here, we document the first report of pulmonary pythiosis infection in two captive coatis in midwest Brazil.

\section{MATERIALS AND METHODS}

Two coatis, a 1-year-old female (Coati 1) and a 4-month-old male cub (Coati 2), were found dead during the rainy season in an outdoor zoo enclosure at the "Universidade Federal do Mato Grosso" Zoo, Cuiabá, Brazil. The facility had 15 coatis in total, with a history of recurrent territorial and sexual fighting and consequent suppurative cutaneous wounds due to bites. During the wet season, respiratory signs like nasal discharge and respiratory distress occurred sporadically. The Coati 1, presenting a non-healing purulent bite wound on its dorsal part, was hospitalized at the time for suspected pneumonia.

The bodies of Coatis 1 and 2 were submitted for necropsy and samples of all organs were collected and fixed in $10 \%$ buffered formalin for routine histopathological processing and hematoxylin and eosin (HE) staining. Special Grocott methenamine silver stains (GMS) stain was performed in the lung to detect negative hyphae profiles, besides immunohistochemistry (IHC) using rabbit polyclonal anti-Pythium insidiosum antibody (noncommercial) (Pesavento et al. 2008), and polymerase chain reaction with primers PI-1: 5'-TTCGTCGAAGCGGACTGCT-3' and PI-2: 5'-GCCGTACAACCCGAGAGTCATA-3' encoding the sequence ITS1 and rDNA of $P$. insidiosum (Pesavento et al. 2008).

\section{RESULTS}

Grossly, Coati 1 and 2 presented unilateral, severe, and chronic granulomatous pneumonia (Fig.1A). The affected lung
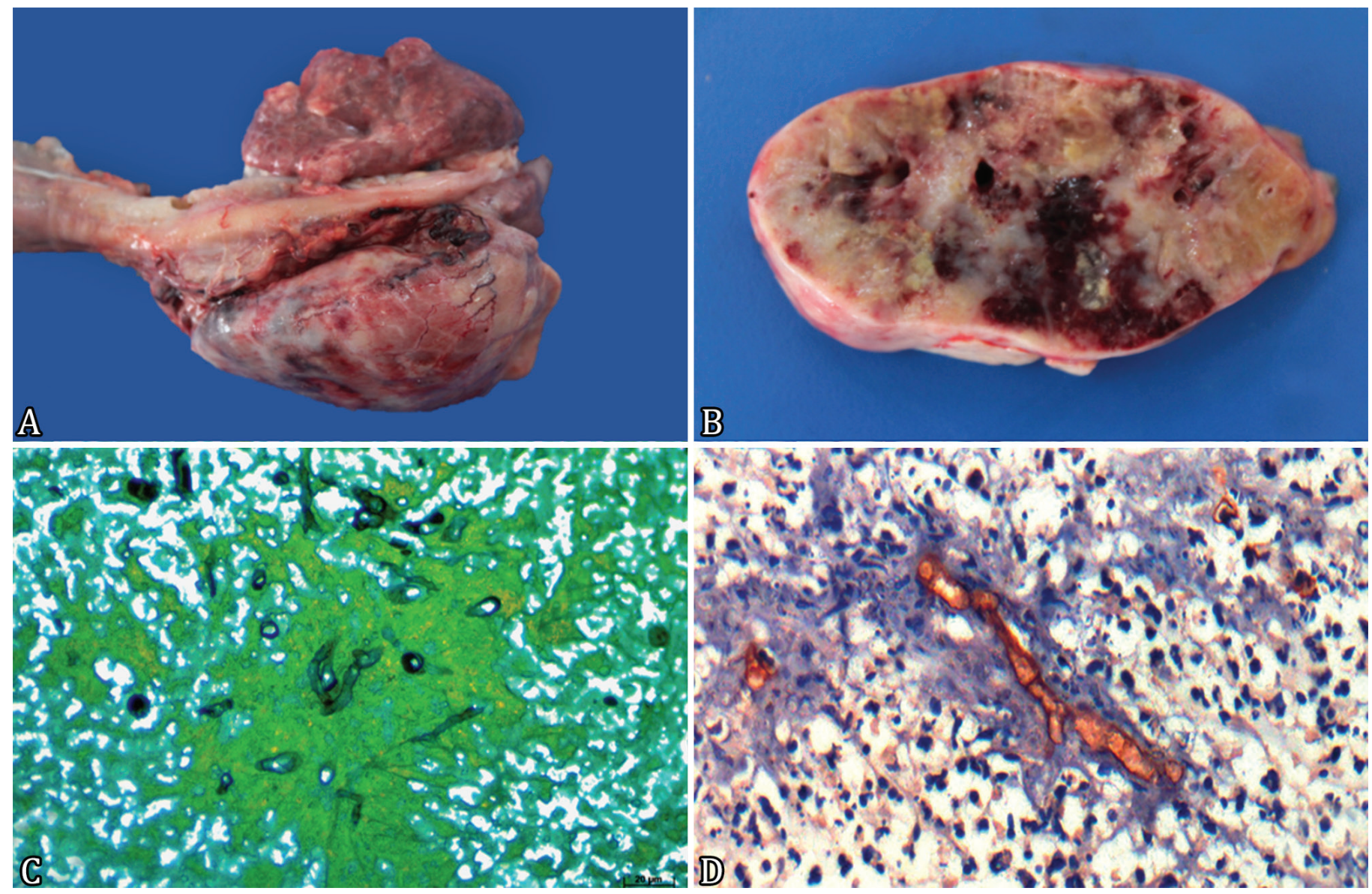

Fig.1. Pythium insidiosum infection, coati, lung. (A) The affected left lung was greatly enlarged. (B) Multiple granulomas scattered through the pulmonary parenchyma. (C) A hypha is situated in the necrotic center. GMS, obj.40x. (D) IHC for Pythium insidiosum shows strong immunostaining on the hyphae-like wall. IHC, obj.40x. 
was greatly enlarged and consolidated, showing numerous coalescent nodular granulomas with yellowish caseous cores (Fig.1B). Coati 1 was emaciated and showed marked subcutaneous thoracic edema, as well as mild mucopurulent nasal flow. In Coati 2, the lung lesions seemed more severe, sometimes presenting a cavernous and lytic pattern. In both cases, a large amount of serofibrinous pleural exudate and multiple points of chronic pleural adherences surrounded the affected lung. Mediastinal lymph nodes were enlarged and embedded among the granulomatous masses.

Microscopically, the lesions were similar with variable intensity in both the coatis. Lung sections showed multiple coalescing granulomas and pyogranulomas characterized by extensive caseous necrosis associated with a dense collection of epithelioid macrophages, eosinophils, degenerate neutrophils, and a mild number of Langhans cells. There was an outer layer of lymphocytes, plasmocytes, and less reactive macrophages and marked proliferation of fibrous connective tissue. Hemorrhage, fibrin thrombi, and necrotizing vasculitis were frequent, but there was no evidence of angioinvasion. Intensely eosinophilic and radiant amorphous material (Splendore-Hoeppli reaction) was frequently observed in these granulomas. Negative hyphae-like profiles were often seen.

Grocott methenamine silver staining of the lung sections revealed several broad, sparsely septate, and irregularly branched hyphae-like organisms that were 3-7 $\mu \mathrm{m}$ in diameter and located predominantly at the Splendore-Hoeppli reaction cores with only a few ones scattered throughout the adjacent areas (Fig.1C). Mediastinal lymph nodes presented lymphoid hyperplasia with marked granulomatous inflammation. The hyphae-like organisms were consistently found in the pulmonary granulomas. There was no angioinvasion or hyphae in the lymphnodes. Hyphae-like organisms were regularly marked using the rabbit polyclonal anti-Pythium insidiosum antibody (non-commercial) (Fig.1D)

Environmental enclosure water, nasal secretions, and a cutaneous punch biopsy of the coati 1 were collected for pathological and epidemiologic investigation. The skin biopsy showed pyogranulomatous dermatitis and granulation tissue. However, hyphae-like organisms were not observed. All samples tested positive by polymerase chain reaction with primers PI-1: 5'-TTCGTCGAAGCGGACTGCT-3' and PI-2: 5'-GCCGTACAACCCGAGAGTCATA-3' encoding the sequence ITS1 and rDNA of P.insidiosum as indicated by the amplification fragment $105 \mathrm{pb}$. All attempts of culture and isolation of $P$. insidiosum from fresh tissues were unsuccessful.

\section{DISCUSSION}

Pythiosis is a well-described condition that manifests as a chronic and progressive granulomatous disease. Its etiologic agent, Pythium insidiosum, is a oomycete pathogen frequently associated with tropical or subtropical aquatic environments (Gaastra et al. 2010). Brazil is endemic for this disease and its warm temperatures with long rainy seasons through the year are highly favorable for the growth and proliferation of this pathogen (Tabosa et al. 2004, Machado et al. 2016). These cases were unique because the primary site of infection appeared to be the lungs and the presentation occurred in more than one animal from the same group, in contrast to the individual reports described till date (Goad 1984, Heath et al. 2002, Camus et al. 2004, Kepler et al. 2017). To the best of our knowledge, this is the first reported case of pythiosis in coatis. This report broadens the spectrum of the disease in non-domestic species. Pythiosis should be included as a differential diagnosis of coatis and zoo animals presenting unspecified respiratory signs or non-healing wounds, especially in endemic regions.

There are very few reports of pulmonary pythiosis. In most cases, it occurs as a consequence of metastatic spread within the progression of the disease in its systemic form, or through aspiration secondary to nasal infection as already described in sheep, horses, and dogs (Reis et al. 2003, Tabosa et al. 2004, Ubiali et al. 2013).

Pulmonary pythiosis as a primary infection is rare and includes only singular case reports in a horse, human, dog, and captive jaguar until now (Goad 1984, Heath et al. 2002, Camus et al. 2004, Kepler et al. 2017). Similar to these coatis, there was no evidence or previous history of wounds or infection at any other site, except in the equine case. This horse previously presented cutaneous pythiosis, but the pulmonary infection was not related to it.

The disease typically involves lesions on parts of the body that have come in contact with warm, stagnant water containing motile zoospores, and infection occurs due to a high tropism that the pathogen has for damaged tissue (Gaastra et al. 2010). In the coati from the group suspected of pneumonia and presenting the skin wound, amplification of the homologous sequence of $P$. insidiosum occurred. However, no hyphae-like organisms were observed in histological sections of skin biopsy of the affected site, and clinical correlation was not possible.

In these cases, the pulmonary infection most likely occurred through inhalation or ingestion with subsequent aspirations of contaminated water containing the pathogen. The pathogen was detected in a nasal swab from a coati of the same group, which suggests that the possible route was through inhaled aerosolized zoospores as seen in a similar case of a Central American jaguar (Camus et al. 2004)

Clinical signs of localized pulmonary pythiosis are usually non-specific, including chronic coughing, dyspnea, and exercise intolerance, as well as nasal discharge, anorexia, weight loss, decreased appetite, anemia, and hypoproteinemia (Goad 1984, Heath et al. 2002, Camus et al. 2004, Kepler et al. 2017). No clinical signs were observed in these two coatis, but their group had a history of respiratory distress and the pathological findings were consistent with these signs. The subcutaneous edema in the female most likely occurred due to hypoproteinemia, as implied by the poor body condition.

The gross and histologic appearance of the lesions of these cases were very similar to those previously described (Martins et al. 2012, Ubiali et al. 2013). When infection occurs through metastatic spread along lymphatics, the granulomas are randomly distributed in both lungs in a miliary pattern (Reis et al. 2003, Tabosa et al. 2004, Ubiali et al. 2013). When pythiosis is restricted to the lungs, the lesions tend to be more localized and form a large and compact mass containing multiple granulomas, as observed in the coatis of our report. The unilateral pulmonary consolidation seen here was also observed in the jaguar case (Camus et al. 2004). However, "kunkers", characteristic of the equine pythiosis, were not observed (Gaastra et al. 2010).

Microscopically, the eosinophilic pattern of necrosis was predominant and similar to that described in horses 
and sheep (Grooters 2003, Martins et al. 2012, Ubiali et al. 2013). Non-eosinophilic granulomatous infiltrate is more common in cattle and was also present in these cases, but only sporadically (Martins et al. 2012). Despite the presence of severe necrotizing vasculitis within fibrin thrombus in many areas of the pulmonary parenchyma, there was no evidence of hyphae vascular invasion or hematogenous spread to other organs.

While the diagnosis is quite non-specific based only on the histopathological examination, these morphological findings narrow the range of possible etiologic agents to $P$. insidiosum, zygomycetes, and Lagenidium species. Lagenidium spp. primarily affects dogs, and it has been reported in cats and humans. The differential diagnosis between these infections is essential, because they are morphologically similar but differ in the epidemiology, choice of therapy, and prognosis (Grooters 2003, Ubiali et al. 2013).

\section{CONCLUSIONS}

The anatomopathological changes, histologic and molecular findings show that Pythium insidiosum is the cause of granulomatous pneumonia in these coatis.

Due the non-specific clinical signs, pythiosis needs to be considered in the differential diagnosis of respiratory diseases affecting this species in endemic areas.

Acknowledgements.- We extend our gratitude to all the technical and support staff of the "Universidade Federal de Mato Grosso" Zoo for providing the field data.

Conflict of interest statement.- The author(s) declare no potential conflicts of interest with respect to the research, authorship, and/or publication of this article.

\section{REFERENCES}

Buergelt C., Powe J. \& White T. 2006. Abdominal pythiosis in a Bengal tiger (Panthera tigris tigris). J. Zoo. Wildl. Med. 37(2):186-189. <http://dx.doi. org/10.1638/05-003.1><PMid:17312799>

Camus A.C., Grooters A.M. \& Aquilar R.F. 2004. Granulomatous pneumonia caused by Pythium insidiosum in a central American jaguar, Panthera onca. J. Vet. Diagn. Invest. 16(6):567-571. <http://dx.doi.org/10.1177/104063870401600612> $<$ PMid:15586573>

Desbiez A.L.J. \& Borges P.A.L. 2010. Density, habitat selection and observations of South American coati Nasua nasua in the central region of the Brazilian Pantanal wetland. Small Carnivore Conserv. 42:14-18.

Gaastra W., Lipman L.J., De Cock A.W., Pege R.B., Scheurwater J., Vilela R. \& Mendonza L. 2010. Pythium insidiosum: an overview. Vet. Microbiol. 146(1/2):1-16. <http://dx.doi.org/10.1016/j.vetmic.2010.07.019> $<$ PMid:20800978>
Gaddis K.L. \& Brinkman E.L. 2017. What Is Your Diagnosis? J. Am. Vet. Med. Assoc. 250(11):1231-1233. <http://dx.doi.org/10.2460/javma.250.11.1231>

Goad M.E.P. 1984. Pulmonary pythiosis in a horse. Vet. Pathol. 21(2):261-262. <http://dx.doi.org/10.1177/030098588402100224><PMid:6730214>

Grooters A.M. 2003. Pythiosis, lagenidiosis, and zygomycosis in small animals. Vet. Clin. N. Am., Small Anim. Pract. 33(4):695-720.<http://dx.doi. org/10.1016/s0195-5616(03)00034-2> <PMid:12910739>

Heath J.A., Kiehn T.E., Brown A.E., LaQuaglia M.P., Steinherz L. J., Bearman G., Wong M. \& Steinherz P.G. 2002. Pythium insidiosum pleuropericarditis complicating pneumonia in a child with leukemia. Clin. Infect Dis. 35(6):e60-e64. <http://dx.doi.org/10.1086/342303><PMid:12203186>

Hedgpeth D. 2018. Wild horse dies of 'swamp cancer' at Chincoteague Island, others sickened. Avaialable at <https://www.washingtonpost.com> Accessed mar 16, 2020

Kepler D., Cole R., Lee-Fowler T., Koehler J., Shrader S. \& Newton J. 2017. Pulmonary pythiosis in a canine patient. Vet. Radiol. Ultrasound 60(2):e20-e23. <http://dx.doi.org/10.1111/vru.12516> <PMid:28547920>

Machado N.G., Biudes M.S., Querino C.A.S., Danelichen V.H.M. \& Velasque M.C.S. 2016. Seasonal and interannual pattern of meteorological variables in Cuiabá, Mato Grosso state, Brazil. Revta Bras. Geof. 33(3):1-12. <http://dx.doi.org/10.22564/rbgf.v33i3.949>

Martins T.B., Kommer G.D., Trost M.E., Inkelmann M.A., Fighera R.A. \& Schild A.L. 2012. A comparative study of the histopathology and immunohistochemistry of pythiosis in horses, dogs and cattle. J. Comp. Pathol. 146(2/3):122-131. <http://dx.doi.org/10.1016/j.jcpa.2011.06.006> <PMid:21824626>

Pesavento P.A., Barr B., Riggs S.M., Eigenheer A.L., Pamma R. \& Walker R.L. 2008. Cutaneous pythiosis in a nestling white-faced ibis. Vet. Pathol. 45(4):538-541. <http://dx.doi.org/10.1354/vp.45-4-538><PMid:18587102>

Reis J.L. Jr, de Carvalho E.C., Nogueira R.H., Lemos L.S. \& Mendoza L. 2003. Disseminated pythiosis in three horses. Vet Microb. 96(3):289-295. <http://dx.doi.org/10.1016/j.vetmic.2003.07.005><PMid:14559176>

Tabosa I.M., Riet-Correa F., Nobre V.M.T., Azevedo E.O., Reis-Junior J.L. \& Medeiros R.M.T. 2004. Outbreaks of pythiosis in two flocks of sheep in northeastern Brazil. Vet. Pathol. 41(4):412-415.<http://dx.doi.org/10.1354/ vp.41-4-412><PMid:15232143>

Ubiali D.G., Cruz R.A., De Paula D.A, Silva M.C., Mendonça F.S., Dutra V., Nakazato L., Colodel E.M. \& Pescador C.A. 2013. Pathology of nasal infection caused by Conidiobolus lamprauges and Pythium insidiosum in sheep. J. Comp. Pathol. 149(2/3):137-145. <http://dx.doi.org/10.1016/j.jcpa.2012.12.002> <PMid:23375916>

Videla R., van Amstel S., O’neill S.H., Frank L.A., Newman S.J., Vilela R. \& Mendonza L. 2012. Vulvar pythiosis in two captive camels (Camelus dromedarius). Sabouraudia 50(2):212-224. <http://dx.doi.org/10.3109 /13693786.2011.588970> <PMid:21696258>

Wellehan J.F., Farina L.L., Keoughan C.G., Lafortune M., Gooters A.M., Mendonza L., Brown M., Terrell S.P., Jacobson E.R. \& Heard D.J. 2004. Pythiosis in a dromedary camel (Camelus dromedarius). J. Zoo. Wildl. Med. 35(4):564568. <http://dx.doi.org/10.1638/03-098><PMid:15732604> 